\title{
ACID-BASE BALANCE, RENAL FUNCTION, AND GASTRIC SECRETION DURING HYPOCHLOREMIA IN THE DOG ${ }^{2}$
}

\author{
By JOSEPH B. KIRSNER AND KATHRYN KNOWLTON \\ (From the Department of Medicine, University of Chicago, Chicago)
}

(Received for publication December 5, 1940)

The mechanism of the severe nitrogen retention seen in extrarenal conditions such as pyloric stenosis or intestinal obstruction has not been established conclusively. Some investigators attribute it to transient renal insufficiency of a purely functional character $(1,2)$. Others $(3,4)$ believe that renal function is essentially unaffected and relate the azotemia directly to the hypochloremia. However, marked nitrogen retention has been observed frequently in the presence of normal or high levels of plasma chloride $(5,6)$. Kerpel-Fronius (7), furthermore, has shown experimentally that azotemia is not a complication of hypochloremia in the absence of dehydration and also that azotemia does develop in dehydration without hypochloremia. The purpose of the present study was to clarify the problem of extrarenal azotemia by studying the effects of a gradually induced hypochloremia on the acid-base equilibrium and renal function in the dog. The investigation also includes an analysis of the histamine-stimulated gastric secretion removed during these experiments.

\section{METHOD OF STUDY}

Chloride deprivation was gradually produced by the intermittent withdrawal of the gastric contents. It was desirable to remove the gastric juice under conditions otherwise as nearly normal as possible. For this purpose two healthy female dogs were operated upon under ether anesthesia. A special gold-plated cannula ${ }^{2}$ was intro-

\footnotetext{
1 Read before the Central Society for Clinical Research, November 1, 1940.

2 The gastrostomy cannula employed was devised by Dr. Alfred J. Klein of the Department of Medicine and is similar to that described by Dragstedt (Surg., Gynec., and Obst., 1933, 56, 799). In the quantitative collection of gastric juice intermittently over a period of weeks, the addition of a plunger to Dragstedt's cannula has proved useful. The cannula proper consists of a brass tube with an internal diameter of $1.1 \mathrm{~cm}$. and is $7.5 \mathrm{~cm}$. in length. The circular flange at the proximal end has a diameter of $3.5 \mathrm{~cm}$. Attached to the cap, which screws on the distal end of the cannula, is a closed hollow brass cylinder so constructed in diameter and length that it
}

duced into the stomach and was brought through the abdominal wall to the exterior. After recovery from the operation, the dogs were placed on a liberal diet with added vitamins. The chloride content of the food was carefully determined and the intake of salt was maintained at a low level almost constantly except for one short period during which food with a higher salt content was inadvertently used. The chloride intake in dog 14 (weight $7.6 \mathrm{kgm}$.) averaged $315 \mathrm{mgm}$. daily, excluding seven days when the daily intake approximated 499 mgm. The chloride intake in dog 35 (weight $11.0 \mathrm{kgm}$.) averaged $467 \mathrm{mgm}$. daily, except for one week during which the daily amount rose to $746 \mathrm{mgm}$. Both dogs received a liberal allowance of chloride-free water which they drank freely throughout the experiment. In dog 14 the intake averaged $237 \mathrm{cc}$. daily for most of the experimental period; this amount was increased to $366 \mathrm{cc}$. daily during the final four weeks. Dog 35 received 331 cc. daily at first. The intake was then increased to 462 cc. and during the last seven days averaged $975 \mathrm{cc}$. (including $100 \mathrm{cc}$. of $2 \frac{1}{2}$ per cent sodium citrate and 300 cc. 5 per cent glucose in distilled water intravenously).

The weight of the animals was checked every seven to fourteen days. The serum chloride, carbon dioxide and $\mathrm{pH}$, and the blood urea nitrogen were determined at weekly intervals (8); in addition, renal function in dog 35 was measured by the urea clearance method of Van Slyke (9). The urine was collected for two hours in these studies. After a control period of several weeks, the removal of gastric contents was begun. The dogs were trained to stand quietly on a table and the secretion of gastric juice was stimulated with hourly subcutaneous injections of histamine, the average dose ranging from 0.33 to $0.50 \mathrm{mgm}$. in $\operatorname{dog} 14$ and from 0.50 to $1.0 \mathrm{mgm}$. in dog 35. The contents were collected in glass Soxhlet

completely fills the lumen of the cannula. Both the cannula and the plunger are gold-plated. The introduction into the stomach is simple. An incision is made in the anterior surface of the antrum just long enough to permit insertion of the flange. Two pursestring sutures are taken in the stomach around the shaft of the cannula and the omentum is wrapped around the shaft. The distal end of the cannula is brought to the outside through a stab wound in the abdominal wall. There has been no leakage with subsequent excoriation of the skin and no loss of gastric juice in dogs prepared by this method. On withdrawal of the cap and plunger there is an immediate flow of gastric contents undiluted by materials which usually accumulate in the shaft of a cannula with a simple cap. 


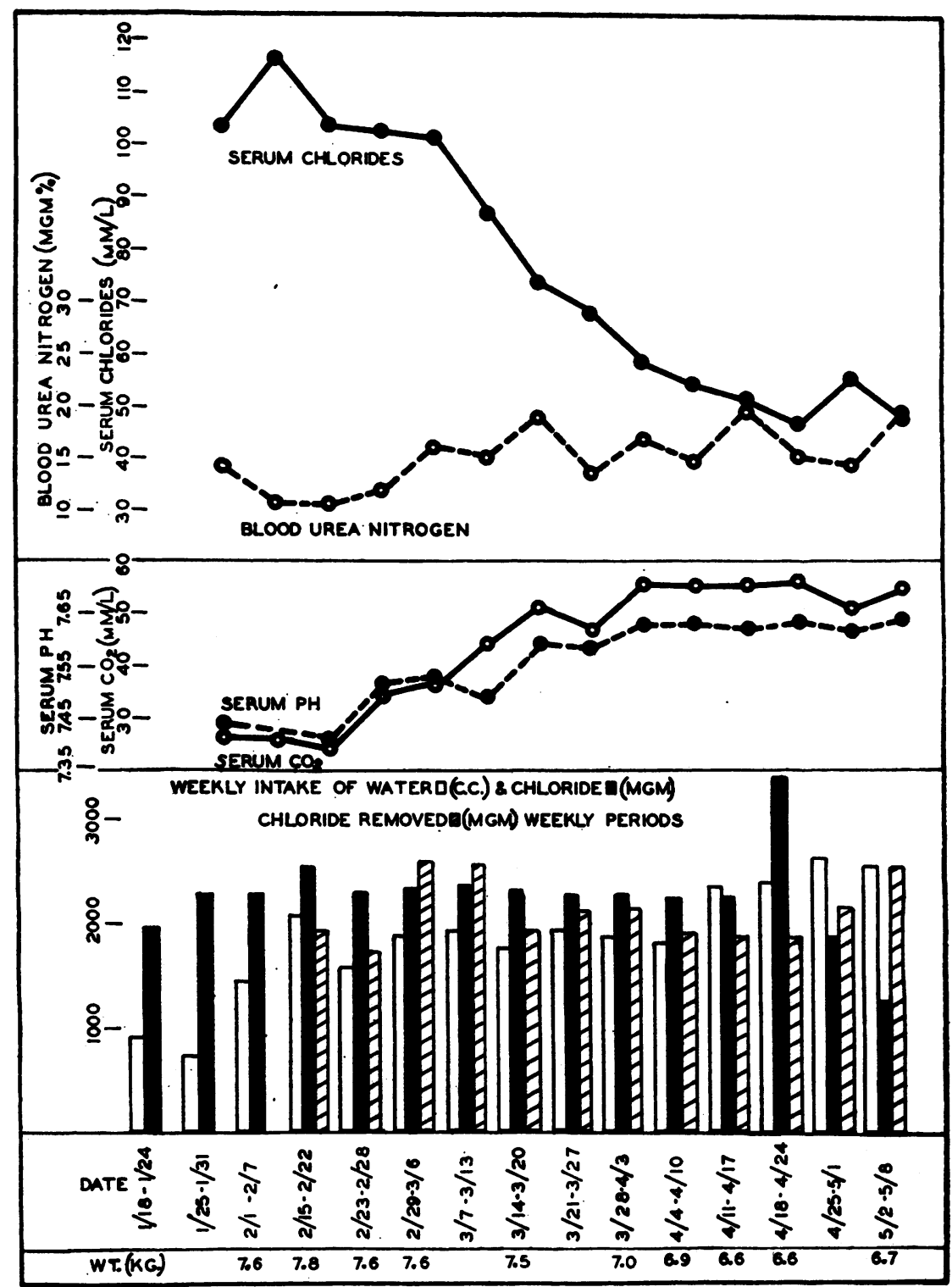

Fig. 1. The Effect of Gradual Chloride Depletion on the Acid-base Balance and Blood Urea Nitrogen in Dog Number 14

flasks, after removal of the screw-cap plunger from the cannula, for three hours each day. Food and liquids were placed in the cages after each collection. Accurate records were kept of the volume of secretion removed daily; the $\mathrm{pH}$ was determined with a Beckman $\mathrm{pH}$ meter; the chlorides were measured by the method of Van Slyke and Sendroy (8). It was impossible to prevent the occasional accumulation of saliva in the stomach; regurgitation of bile, however, was infrequent.

\section{RESULTS}

The gastric contents were withdrawn intermittently from dog 14 over a period of seventy-four days. It will be noted (Figure 1) that the serum chloride decreased gradually from an average of $105.5 \mathrm{mM}$. per liter to the low value of $46.8 \mathrm{mM}$. per liter, a reduction of 56 per cent. The serum carbon dioxide rose to a peak of $56.2 \mathrm{mM}$. per liter, and the $\mathrm{pH}$ increased to a level of 7.63. The total anion concentration $\left(\mathrm{Cl}\right.$ and $\left.\mathrm{HCO}_{3}\right)$ decreased from an average of $135 \mathrm{mM}$. per liter, when the acid-base balance was normal, to 103.1 $\mathrm{mM}$. per liter as the hypochloremia became severe. Despite the severe hypochloremia and alkalosis, 
TABLE I

Gastric secretion during hypochloremia

\begin{tabular}{|c|c|c|c|}
\hline & \multicolumn{3}{|c|}{ Gastric juice (daily values) } \\
\hline & Volume & pH & Chloride \\
\hline $\begin{array}{l}\text { Dog 14: } \\
\text { a. Period of normal blood chloride } \\
\text { (103.8-101.2 mM. per liter) } \\
\text { b. Severe hypochloremia } \\
(55.2-46.8 \mathrm{mM} \text {. per liter) }\end{array}$ & $\begin{array}{c}\text { cc. } \\
70-150 \\
\text { average } 99 \\
56-124 \\
\text { average } 84\end{array}$ & $\begin{array}{c}1.20-1.43 \\
\text { average } 1.30 \\
1.40-2.70 \\
\text { average } 1.87\end{array}$ & $\begin{array}{c}\text { mM. per liter } \\
132-148 \\
\text { average } 138 \\
92-126 \\
\text { average } 117\end{array}$ \\
\hline $\begin{array}{l}\text { Dog 35: } \\
\text { a. Period of normal blood chloride } \\
\text { (108.4-98.4 mM. per liter) } \\
\text { b. Severe hypochloremia } \\
\text { (56.4-38.9 mM. per liter) }\end{array}$ & $\begin{array}{c}87-170 \\
\text { average } 121 \\
46-159 \\
\text { average } 123\end{array}$ & $\begin{array}{c}1.18-2.41 \\
\text { average } 1.43 \\
1.45-1.65 \\
\text { average } 1.51\end{array}$ & $\begin{array}{c}132-148 \\
\text { average } 140 \\
112-140 \\
\text { average } 131\end{array}$ \\
\hline
\end{tabular}

the rise in blood urea nitrogen was slight, ranging from 14.0 to $19.7 \mathrm{mgm}$. per cent during the period of chloride loss. It will be noted (Table I, Figure 2) that the volume and chloride content of the gastric juice decreased moderately while the $\mathrm{pH}$ rose slightly. Weight loss amounted to 1.1 kgm., or 14 per cent of the body weight, and oc- curred chiefly during the latter stages of the experiment. Weakness gradually increased and on the seventy-fourth day the withdrawal of gastric juice was discontinued. The dog was found dead in its cage several days later. At necropsy the lungs were congested but there was no evidence of pneumonia. The kidneys showed early postmortem changes. The glomeruli and tubules were normal on microscopic examination, although considerable protein precipitate was present in the glomerular spaces and in the tubules. Calcium was not found in the kidney, using von Kossa's silver nitrate stain. One parathyroid gland was successfully located and appeared entirely normal on histologic examination.

The gastric contents were withdrawn intermittently from dog 35 for eighty-six days. The serum chloride, carbon dioxide and $\mathrm{pH}$ remained normal for thirty-nine days, by which time $13,510 \mathrm{mgm}$. of chloride had been removed (Figure 3 ). In

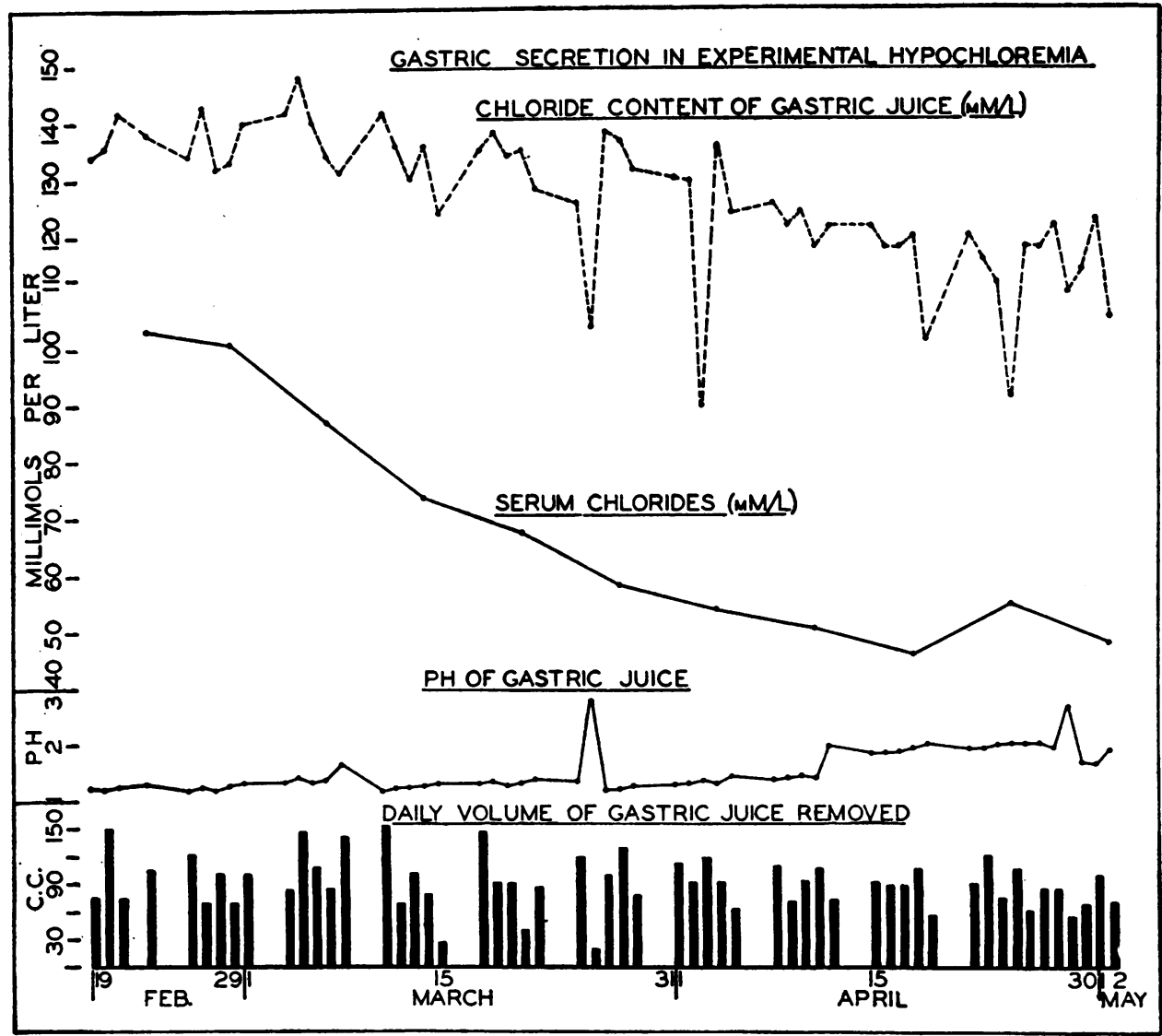

Fig. 2. Effect of Gradual Hypochloremia on Volume, pH, and Chloride Content of Histamine-stimulated Gastric Secretion in Dog Number 14 


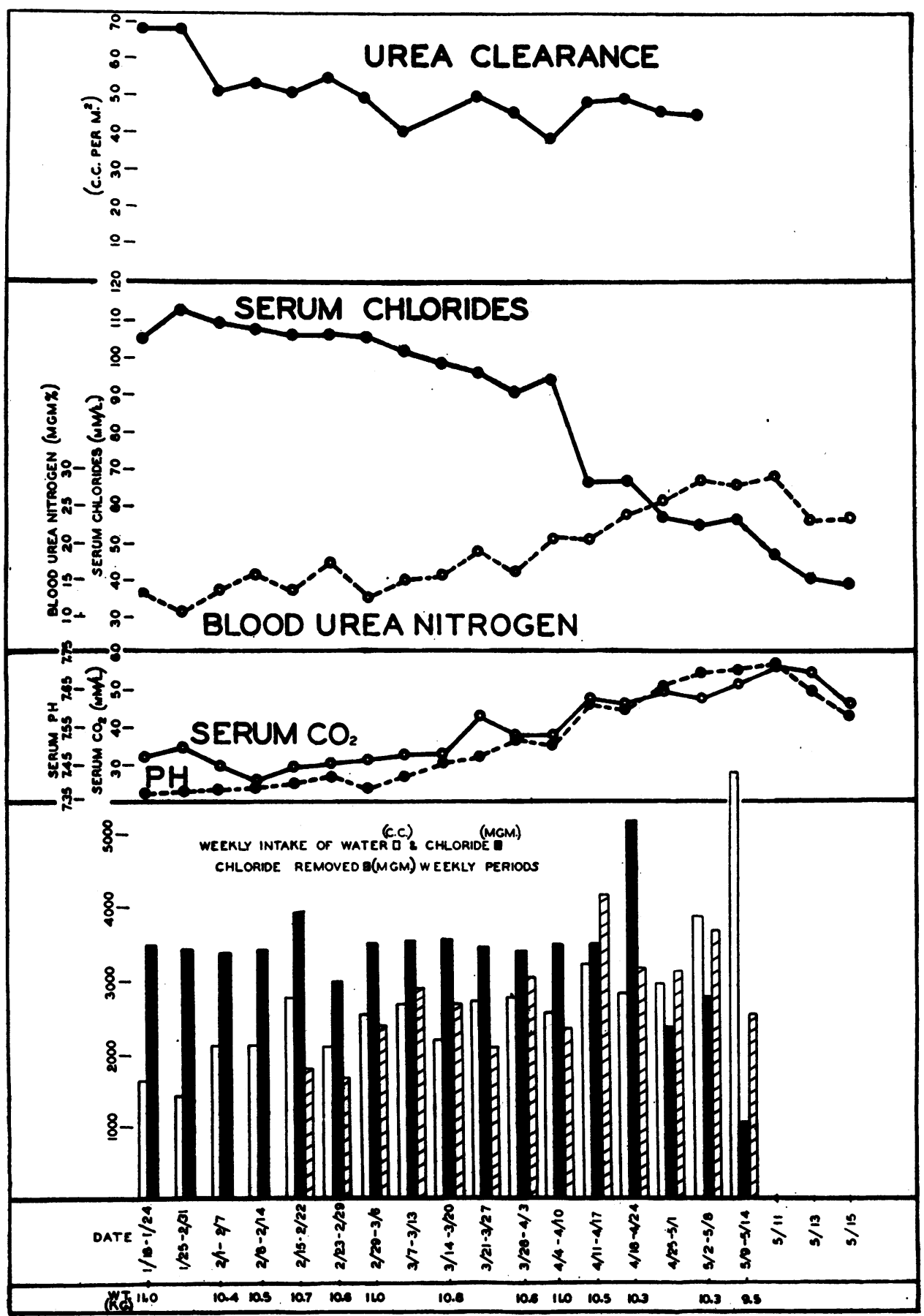

Fig. 3. The Effect of Gradual Chloride Depletion on the Acid-base Balance, Blood Urea Nitrogen, and Urea Clearance in Dog Number 35 
the following week the serum chloricle decreased appreciably and eventually diminished from an average of $107.3 \mathrm{mM}$. per liter to the low level of $38.9 \mathrm{mM}$. per liter, a reduction of 64 per cent. The serum carbon clioxide rose to a height of $57.5 \mathrm{mM}$. per liter and the $\mathrm{pH}$ to a level of 7.72 . During the final two days the serum carbon clioxide and $\mathrm{pH}$ decreased despite the progressive hypochloremia. The total anion concentration $\left(\mathrm{Cl}\right.$ and $\left.\mathrm{HCO}_{: 3}\right)$ diminished from an average of $131 \mathrm{mM}$. per liter, when the acid-base balance was normal, to the very low value of $82.1 \mathrm{mM}$. per liter during the final stages of the hypochloremia. The blood urea nitrogen in this animal reached a peak of 28.6 mgm. per cent. This moderate elevation of the blood urea nitrogen is in marked contrast to the high values usually found in acute hypochloremia and alkalosis. The values ranged from 10.9 to $17.1 \mathrm{mgm}$. per cent when the serum chloricle was normal and from 16.8 to $28.6 \mathrm{mgm}$. per cent during the hypochloremia. The total plasma nitrogen, non-protein nitrogen, and plasma proteins were normal several hours before death, the values being 10.14 grams per liter, 0.40 grams per liter, and 6.09 grams per cent, respectively. Excretion of ingested water was delayed in both dogs as the chloride loss was intensified. However, after diuresis appeared, urine volumes cluring the hypochloremia closely approximated those obtained when the acid-base balance was normal. The urine volumes in dog 35 averaged $1.72 \mathrm{cc}$. per minute during the control period and $1.46 \mathrm{cc}$. per minute during chloride deprivation. Urine collections (two-hour periods) were delayed until diuresis occurred. The urea clearances remained normal throughout the ex-

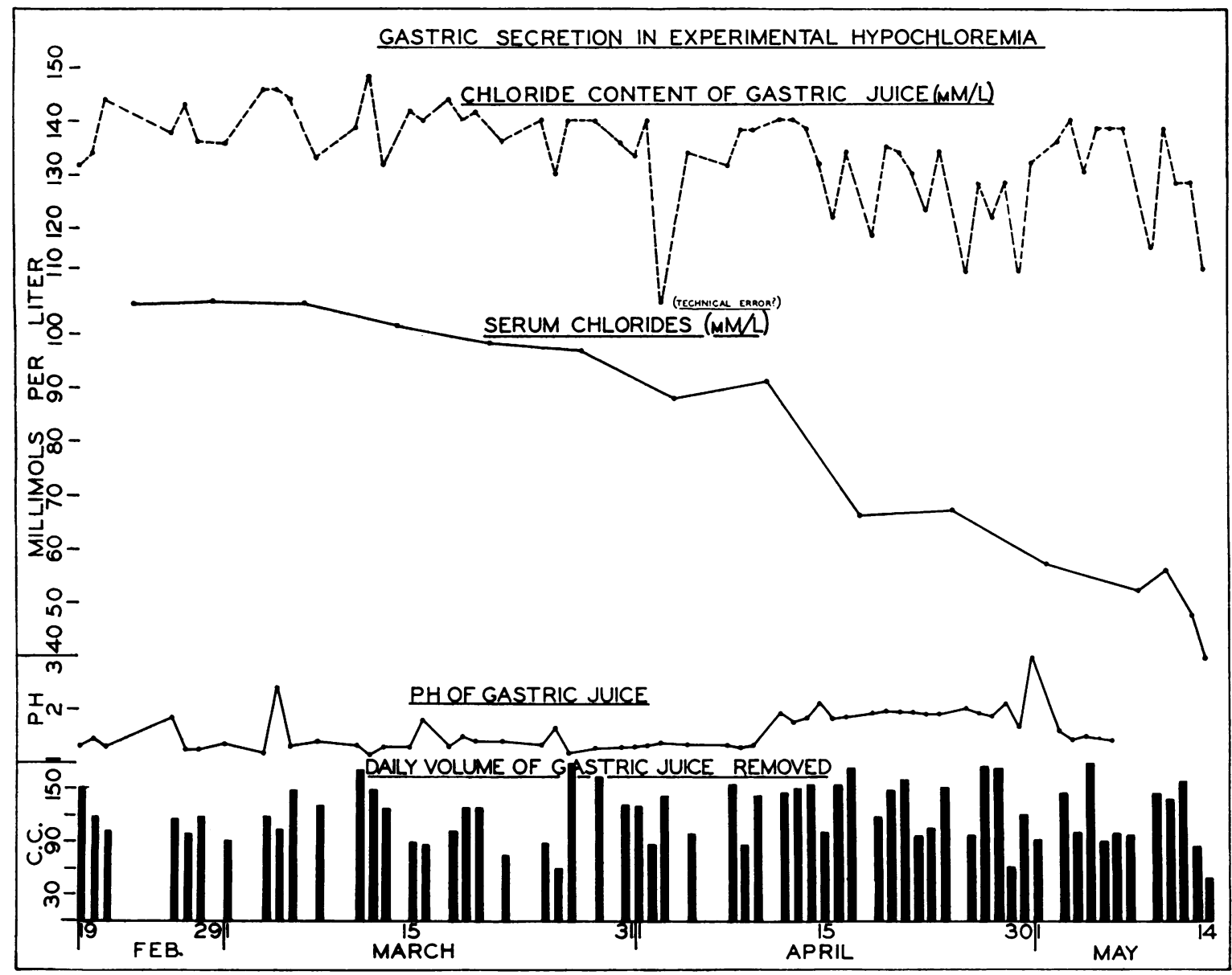

Fig. 4. Effect of Gradual Hypochloresia on Volume, pH, and Chloride Content of Histanine-stinleated Gastric Secretion in Dog Number 35 


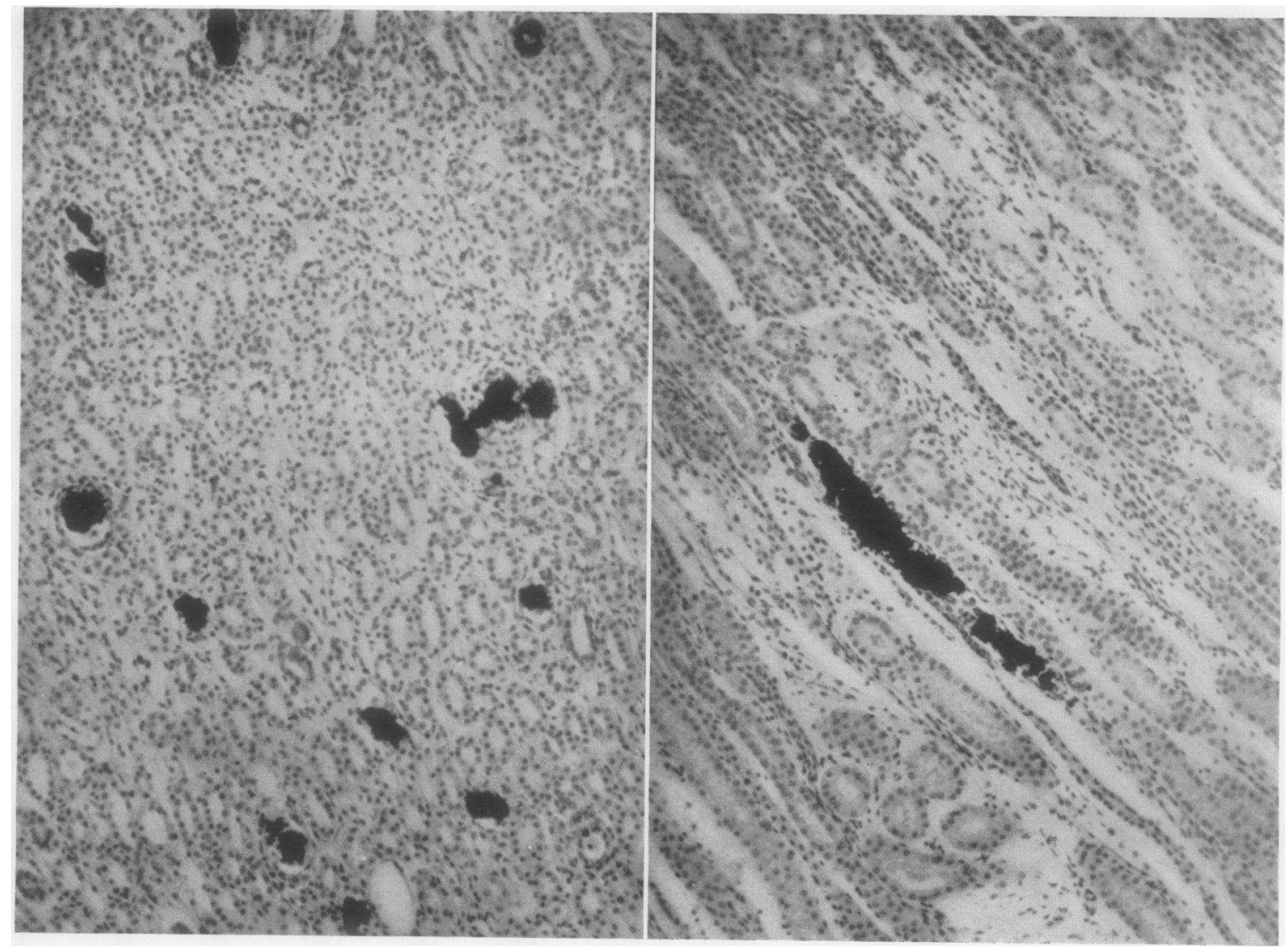

Fig. 5. Photomicrograph Demonstrating Presence of Calcium Precipitate in Renal Collecting Tubules in Dog Number 35

periment, ranging from $68.9 \mathrm{cc}$ to $41.8 \mathrm{cc}$. of blood per square meter when the serum chloride was normal, and from 50.9 cc. to 47.2 cc. during the chloropenia, except for one value of $38.7 \mathrm{cc}$. These results do not differ greatly from the average urea clearances reported for the normal clog by other authors. Rhoads ot al. (10) obtained an average clearance of $49.8 \mathrm{cc}$; Ralli ct al. (11), 57.7 cc.; and Jolliffe and Smith (12), 55.3 cc. In $\log 35$ the average daily volume of gastric juice was unchanged, the $\mathrm{pH}$ rose slightly, and the decrease in chloride content was comparatively small (Table I, Figure 4). Dog 35 lost $1.5 \mathrm{kgm}$., or 13.5 per cent body weight, almost entirely cluring the last seven lays of the experiment. Muscular hyperirritability developed on the eightyeighth day and the animal died several hours later. At necropsy the glomeruli were normal and there was slight focal tubular atrophy with cortical scarring. The lumina of many of the collecting tu- bules were filled with blue staining masses which proved to be calcium (Figure 5). Analysis of the skin, skeletal muscle, liver, and kidney in both dogs revealed a markedly reduced chloride content. Direct measurements of the blood sodium were not made in these experiments. However, the fact that the sum of the anions $\left(\mathrm{Cl}\right.$ and $\left.\mathrm{HCO}_{3}\right)$ was much below normal indicates a decreased concentration of cation, i.c., sodium.

\section{DISCUSSION}

Inasmuch as the gastric juice is derived from water and electrolytes taken from the blood plasma, the continued loss of gastric secretion involves a consiclerable loss of chloride and a much smaller but significant depletion of sodium. The loss of anion (C1) is replaced by an extension of bicarbonate, and therefore does not alter the tutal electrolyte value at first, whereas loss of base is not replaceable except from the diet and, more- 
over, carries with it an equivalent quantity of bicarbonate ion. The deficit of base is accompanied by a corresponding loss of extracellular water, leading to an extensive reduction in the volume of extracellular fluid (13). Severe nitrogen retention usually accompanies such acute disturbances in the plasma electrolytes and fluid (14, 15, 16). Experimentally, Dragstedt and Ellis (17) found an elevation of the urea nitrogen from 12 to $154 \mathrm{mgm}$. and of the non-protein nitrogen from 27 to $180 \mathrm{mgm}$. when the whole blood chloride decreased from 300 to $108 \mathrm{mgm}$. of chloride. The pathogenesis of the azotemia has not been clearly understood, although several explanations have been offered. Blum attributed the rise in blood urea to reabsorption of urea through the tubules of the kidney in order to raise the subnormal osmotic pressure of the plasma. Urea, however, is a crystalloid and, even if reabsorbed, would not regulate the osmotic pressure of the plasma as originally conceived for it diffuses freely through all the tissues of the body. As McCance (15) points out, nothing can act as an efficient substitute for an extracellular electrolyte unless its distribution is limited to the extracellular fluids.

A second cause which has been given for the development of extrarenal azotemia is the increased protein catabolism of dehydration. $\mathrm{Nu}$ merous investigators $(18,19)$ have shown that deprivation of water alone may accelerate the breakdown of protein. McCance (20) found during acute salt deficiency produced by diet and sweating that, with a reduction in the volume of body fluids of 28 to 38 per cent, the subjects were in negative nitrogen balances. Both in clinical and experimental salt deficiency the loss of chloride is abrupt and is rapidly followed by a marked loss of body water. The nitrogen retention, therefore, may be explained simply on the basis of excessive protein breakdown associated with anhydremia $(21,22$, 23). The azotemia in hypochloremia has been attributed also to impaired renal function secondary to dehydration $(24,25)$. This concept is supported by the findings of Landis et al (26) in that the mild elevation of blood urea nitrogen following restriction of sodium chloride was accompanied by a slightly diminished average twentyfour-hour urea clearance. The conventional onehour clearances were normal. McCance and Widdowson (27) found a decrease of the creatinine, sucrose, inulin, and urea clearances during acute salt deficiency. These decreases were attributed to diminished glomerular filtration and to increased tubular reabsorption of urea. Eventual reduction of the volume of blood plasma by the process of dehydration causes physical changes in the blood and in the mechanics of its circulation which greatly reduce volume flow through the kidneys, with the result that accuracy of renal function is impaired. These changes include: increased colloidal osmotic pressure; increased blood viscosity, decreased blood volume; a reduction in the number of " active glomeruli "; and a decrease in the rate of circulation. Regardless of the specific mechanisms operative, it is apparent that the basic renal disturbance is not one of primary or secondary renal disease but of impaired renal function secondary to dehydration.

This study, in contrast to the previous investigations, indicates that a gradually induced hypochloremia is not necessarily accompanied by severe nitrogen retention. Ambard and his associates (28) and Hiatt (29) have made similar observations. The decisive factor which determines the extent of azotemia during hypochloremia appears to be the degree and rapidity of dehydration associated with the chloride loss. The extracellular fluid was not measured but, presumably, was diminished. Evidence for its decrease is to be found in the significant loss of weight sustained by both dogs and also in the established fact that loss of body fluid occurs with a decrease in serum electrolytes (30). Since the animals drank considerable amounts of chloride-free water daily, it would appear that dehydration did not exist in the sense of deprivation of water, but was present in the sense that loss of body fluid accompanied the loss of electrolytes. However, the dogs apparently were able to make rather satisfactory adjustments to severe changes in the electrolyte balance during most of the experiment. The normal urea clearances and the finding of normal nitrogenous constituents in the blood several hours before death are evidence of adequate renal function. The mild elevation of blood urea nitrogen may be considered as indicative of a decrease in renal function too small to be detected by the usual clearances, as suggested by the work of Landis. The explanation of such an assumed impairment of renal function, however, is not easily hypothe- 
sized. The urinary volumes were excellent, although we observed, as have other workers, an unexplained delay in water diuresis in these animals.

The calcium precipitate observed in the renal collecting tubules in dog 35 is of considerable interest since it is not usually present in the normal dog and was not found in $\operatorname{dog} 14$. This condition was described originally by Nazari (31) in 1904 in two patients with prolonged vomiting secondary to pyloric stenosis. Many similar reports subsequently appeared $(32,33,34)$ but the mechanism of the condition is not entirely clear. Calcium salts are not infrequently deposited in necrotic kidney cells. Martz and others believe that the secretion of an acid urine during severe alkalosis makes the cell fluids of the kidney even more alkaline and thereby favors the precipitation of calcium. Hatano (35) was able to prevent this complication during hypochloremia by the intravenous injection of sodium chloride which tended to correct the acid-base balance. The use of sodium bicarbonate proved ineffective. Gömöri and his co-workers (36) have frequently observed fat degeneration with necrosis and calcification in the kidneys of patients dying of "hypochloremic uremia." Since the kidneys in the present experiment were normal, the calcium precipitate is probably the result of an abnormal physical chemical state in the urine.

The results of the present investigation are in complete accord with other studies in demonstrating that during periods of marked hypochloremia, the gastric mucosa is able to secrete normal amounts of highly acid gastric juice. Dragstedt and Ellis (17), working on dogs with total gastric pouches, found that the gastric glands continued to secrete in spite of a plasma chloride level lower than one-third of normal; the volume of secretion, however, was reduced and its acidity lessened. Lim and $\mathrm{Ni}$ (37) observed a continued secretion in dogs despite dehydration and a loss of one-half of the total body chloride. Katsch and Mellinghoff (38) and Mellinghoff and Heuschert (39) withdrew gastric juice from patients for ten hours each day for three to five days, removing up to 33 grams of sodium chloride, and produced an average fall in the whole blood chloride of $51 \mathrm{mgm}$. per $100 \mathrm{cc}$. The gastric secretion showed a 20 per cent reduction in volume without significant change in the chloride content. The response to histamine was as good or almost as good on the last day of treatment as it had been on the first. McCance (20) found that salt deficiency produced by diet and sweating tended to reduce the concentration of acid and chloride in gastric juice but that individuals varied widely in their response. Solely, Lagen and Lockhart (40) examined three healthy men over a period of one week on a saltdeficient diet, an increased output of salt being obtained by frequent periods of sweating. They found no significant change in the free acidity or total hydrochloric acid of the gastric juice under these conditions. The degree of salt deficiency, however, was very slight. Nicol and Lyall (41) studied a group of patients with peptic ulcer in whom hypochloremia had been induced by vomiting and concluded that the gastric mucosa could still secrete normal amounts of hydrochloric acid. The blood chloride in one patient had decreased to $60 \mathrm{mM}$. per liter. Hiatt (29) has recently found that the volume and total acidity of the histaminestimulated gastric secretion were decreased in dogs with chloride levels below 65 per cent of normal. The function of the gastric glands is apparently unique, since chloride secretion by other routes, including the skin and choroid plexus, and its excretion via the kidney are diminished or cease completely in the presence of a severe hypochloremia.

\section{SUMMARY}

A gradual depletion of body chloride was produced in two dogs by the intermittent withdrawal of histamine-stimulated gastric juice over periods of seventy-four and eighty-six days. The dogs received a generous diet with added vitamins and a liberal allowance of chloride-free water. The salt intake was maintained at a low level, averaging 315 and $467 \mathrm{mgm}$. daily. At weekly intervals determinations were made of the serum chloride, carbon dioxide, $\mathrm{pH}$ and blood urea nitrogen, and renal function in one animal was measured by the urea clearance method of Van Slyke. In dog 14 the serum chloride decreased from an average of $105.5 \mathrm{mM}$. per liter to $46.8 \mathrm{mM}$. per liter, while in dog 35 the serum chloride decreased from an average of $107.3 \mathrm{mM}$. per liter to $38.9 \mathrm{mM}$. per liter. In dog 14 the carbon dioxide rose to 56.2 $\mathrm{mM}$. per liter and the $\mathrm{pH}$ to 7.63 ; in dog 35 the carbon dioxide rose to a height of $57.5 \mathrm{mM}$. per 
liter and the $\mathrm{pH}$ to 7.72. The blood urea nitrogen in dog 14 ranged from 10.6 to $16.6 \mathrm{mgm}$. per cent when the acid-base balance was normal, and from 13.3 to $19.7 \mathrm{mgm}$. per cent during the hypochloremia. The blood urea nitrogen in dog 35 ranged from 10.9 to $17.1 \mathrm{mgm}$. per cent with a normal acid-base balance and from 16.8 to $28.6 \mathrm{mgm}$. per cent during the chloropenia. Both dogs lost approximately 14 per cent of body weight. There was indirect evidence to suggest that the blood sodium was diminished. Since both animals were allowed to drink as much chloride-free water as desired, dehydration in the ordinary sense of water deprivation was not present. The nitrogenous constituents of the blood in dog 35 were normal shortly before death. The urea clearance remained normal throughout, ranging from 68.9 to $41.8 \mathrm{cc}$. during the control period and from 50.9 to 47.2 cc. during the depletion of body chloride. The excretion of ingested water was delayed in both dogs as the loss of chloride was intensified. In dog 14 there was a moderate decrease in the volume and chloride content of the gastric juice, the $\mathrm{pH}$ rising slightly; while in dog 35 the volume, $\mathrm{pH}$ and chloride content of the gastric juice did not change significantly. Calcium precipitation was observed in the renal collecting tubules of $\operatorname{dog} 35$.

\section{CONCLUSIONS}

1. A severe alkalosis may be induced by the gradual withdrawal of gastric contents without severe or, indeed, even marked nitrogen retention.

2. Such an alkalosis apparently does not produce renal injury detectable either by the urea clearance test or by histologic examination.

3. The secretion of hydrochloric acid by the gastric mucosa is relatively uninfluenced by a profound hypochloremia.

The authors wish to express their appreciation to Drs. Louis Leiter and Walter Lincoln Palmer for their valuable aid in the analysis of the data.

\section{BIBLIOGRAPHY}

1. Haden, R. L., and Guffey, D. C., A case of pernicious vomiting of pregnancy with low blood chloride and marked response to sodium chloride therapy. Am. J. Obst. and Gyn., 1924, 8, 486.

2. Mellinghoff, K., Uber Urämie bei Kochsalzmangel. Deutsche Med. Woch., 1934, 60, 1127.
3. Blum, L., Grabar, P., and Van Caulaert, L., L'Azotémie par manque de sel. Presse Med., 1928, 36, 1411.

4. Rathery, F., and Rudolf, M., Crises d'azotémie aigüe récidivantes, chlorures, sanguins et réserve alcaline. Bull. et Mem. Soc. Med. d. hôp. de Paris, 1928, 52, 1363.

5. Pellegrini, G., Coma diabetico particolarmente complesso. Riforma Med., 1931, 47, 875.

6. Fullerton, H. W., Lyall, A., and Davidson, L. S. P., Treatment of diabetic uraemia with hypertonic glucose solutions. Lancet, 1932, 1, 558.

7a. Kerpel-Fronius, E., Zur pathogenese der "hypochloramischen" Azotämie. Ztschr. f. d. ges. exper. Med., 1936, 97, 733.

b. Idem, Salzmangelzustände und chloroprive Azotämie. Ergeb. inn. Med. u. Kinderhạilk, 1936, 51, 623.

8. Peters, J. P., and Van Slyke, D. D., Quantitative Clinical Chemistry, Vol. 2, Methods. Williams \& Wilkins, Baltimore, 1931, pp. 835, 283, 796, 367.

9. Van Slyke, D. D., and others, Observations on the courses of different types of Bright's disease and on resultant changes in renal anatomy. Medicine, 1930, 9, 257.

10. Rhoads, C. P., and others, The functional effect of explanting one kidney and removing the other. Am. J. Physiol., 1934, 109, 329.

11. Ralli, E. P., Brown, M., and Pariente, A., Urea clearance test in normal dogs. Am. J. Physiol., 1931, 97, 432.

12a. Jolliffe, N., and Smith, H. W., Excretion of urine in dog; urea and creatinine clearance on mixed diet. Am. J. Physiol., 1931, 98, 572.

b. Idem, Excretion of urine in dog; urea and creatinine clearances on cracker meal diet. Am. J. Physiol., 1931, 99, 101.

13. Gamble, J. L., and McIver, M. A., Acid-base composition of gastric secretion. J. Exper. Med., 1928, 48, 837.

14. Glass, J., Untersuchungen über die experimentelle chlorverarmung ihre folgen und die ursache des dechlorurationstodes. Ztschr. f. d. ges. exper. med., 1932, 82, 776.

15. McCance, R. A., Medical problems in mineral metabolism. Lancet, 1936, 1, 643, 704, 765, 823.

16. Lyall, A., and Nicol, B. M., The gastric secretions in experimental hypochloraemia. J. Physiol., 1939, 96, 21.

17. Dragstedt, L. R., and Ellis, J. C., The fatal effect of the total loss of gastric juice. Am. J. Physiol., 1930, 93, 407.

18. Landauer, A., Uber den Einfluss des Wassers auf den organismus. Ungar, Arch. f. Med., 1894, 3, 136.

19. Schiff, E., Wirkung eingeschränkter wassereinfuhr auf den $\mathrm{N}$-und $\mathrm{Cl}$ umsatz und die $\mathrm{NH}_{3}$ Ausscheidung. Monatschr. f. Kinderh., 1919, 15, 593.

20. McCance, R. A., The effect of salt deficiency in man on the volume of extracellular fluids and on the 
composition of sweat, saliva, gastric juice, and cerebrospinal fluid. J. Physiol., 1938, 92, 208.

21. Peters, J. P., Salt and water metabolism in nephritis. Medicine, 1932, 11, 435.

22. Kerpel-Fronius, E., and Butler, A. M., Salt and water losses in diuretin diuresis and their relation to serum nonprotein nitrogen and electrolyte concentrations. J. Exper. Med., 1935, 61, 157.

23. Morawitz, P., and Schloss, J., "Extrarenale" albuminurie und uramie, Klin. Wchnschr., 1932, 11, 1628.

24. Host, N. F., On chloride metabolism. J. Lab. and Clin. Med., 1918, 5, 713.

25. Chabanier, H., and others, Poussée aigüe d'hyperazotémie avec phénomènes urémiques graves liée a une hypochlorémie chez un néphritique chronique; guérison par rechloruration. Presse Med., 1934, 42, 844.

26. Landis, E. M., and others, Observations on sodium chloride restriction and urea clearance in renal insufficiency. J. Clin. Invest., 1935, 14, 525.

27. McCance, R. A., and Widdowson, E. M., The secretion of urine in man during experimental salt deficiency. J. Physiol., 1937, 91, 222.

28. Ambard, L., Stahl, J., and Kuhlmann, D., Azotémie et chloropénie. Arch. d. mal. d. reins, 1933, 7, 465.

29. Hiatt, E. P., Extreme hypochloremia in dogs induced by nitrate administration. Am. J. Physiol., 1940, 129, 597.

30. Darrow, D. C., and Yannett, H., The changes in the distribution of body water accompanying increase and decrease in extracellular electrolyte. J. Clin. Invest., 1935, 14, 266.

31. Nazari, A., Alterazioni renali nella tetania gastrica. Policlin., 1904, 11, 146.

32. Zeman, F. D., Friedman, W., and Mann, L. T., Kidney changes in pyloric obstruction. Proc. N. Y. Path. Soc., 1924, 24, 41.

33. Cooke, A. M., Calcification of the kidneys in pyloric stenosis. Quart. J. Med., 1933, 2, 539.

34. Martz, H., Renal calcification accompanying pyloric and high intestinal obstruction. Arch. Int. Med., $1940,65,375$.

35. Hatano, S., Experimente über kalknephrose bie hypochlorämie. Beitrag. path. Anat., 1939, 102, 316.

36. Gömöri, P., Podhradszky, L., and Kring, J., The significance of circulation in the pathogenesis of extrarenal azotemias. Acta Med. Scandinav., 1939, $102,591$.

37. Lim, R. K. S., and Ni, T. G., Changes in the blood constituents accompanying gastric secretion; chlorine. Am. J. Physiol., 1925, 75, 475.

38. Katsch, G., and Mellinghoff, K., Über Magensaftentziehung. Ztschr. f. Klin. Med., 1933, 123, 390.

39. Mellinghoff, K., and Heuschert, C. A., Blutmengenstudien bei Magensaftentziehung. Klin. Wchnschr., 1934, 13, 1247.

40. Soley, M. H., Lagen, J. B., and Lockhart, J. C., The effect of sodium chloride deficiency on gastric acidity. Am. J. M. Sc., 1938, 196, 88.

41. Nicol, B. M., and Lyall, A., Gastric secretions during pathological hypochloraemia. Lancet, 1939, 1, 144. 